\title{
IMPLEMENTASI MEDIA AUDIOVISUAL DALAM MENINGKATKAN KEMAMPUAN MENULIS SURAT RESMI PADA SISWA KELAS V SD NEGERI WILAYAH I KECAMATAN TEMPE KABUPATEN WAJO
}

\author{
Jawariah \\ SDN Wilayah 1, Kecamatan Soppeng, Kabupaten Soppeng \\ jawariah@yahoo.com.
}

\begin{abstract}
The research aimed to describe the effectiveness level of audiovisual media in improving the ability of learning to write official letter at V grade elementary school student in Region I Kecamatan Tempe Kabupaten Wajo. This research was experimental research posttest only control group design type. The total population in this research was 151 people using total sampling. Sample in this research was clustered on two cluster, $V_{A}$ grade SDN 2 Maddukkelleng students as many as 32 students as experimental class $(X)$ and $V_{B}$ grade SDN 5 Maddukkelleng students as many as 28 students as control class (Y). Technique of collecting data was done by giving test to each cluster, experimental class and control class. The obtained data were analyzed using statistic descriptive technique and analysis experimental technique t-test third design type. This result of this research showed that calculation of coefficient comparison of average score students ability in learning to write official letter between experimental class $(X)$ and control class $(Y)$ was obtained as much as 1,82 higher that t-table in significant level of $95 \%$ that was t.s. $0,95=1,70$, then alternative hypothesis $\left(H_{1}\right)$ accepted. Thus, using audiovisual media was effectively applied in learning to write official letter at $V$ grade elementary school student in Region I Kecamatan Tempe Kabupaten Wajo. Based on this result, the researcher suggested using audiovisual media in learning to write official letter at $V$ grade elementary school student in Region I Kecamatan Tempe Kabupaten Wajo. Because audiovisual media developing student's creativity and imagination, especially in using idea, developing and organizing systematically complete and solid essay. This was applied with the aim of the students can improve their ability to write official letter.
\end{abstract}

Key word : audiovisual, writing official letter

\begin{abstract}
Abstrak
Penelitian ini bertujuan mendeskripsikan tingkat keefektifan penggunaan media audiovisual dalam meningkatkan kemampuan menulis surat resmi siswa Kelas V SD Negeri Wilayah I Kecamatan Tempe Kabupaten Wajo. Penelitian ini adalah penelitian eksperimen jenis posttest only control group design. Populasi dalam penelitian ini adalah keseluruhan siswa kelas V SD Negeri Wilayah I Kecamatan Tempe Kabupaten Wajo, yaitu seluruh siswa kelas $V$ SD Negeri 2 Maddukkelleng dan seluruh siswa kelas V SD Negeri 5 Maddukkelleng, yang berjumlah 151 orang dengan menggunakan sampel total (total sampling). Sampel dalam penelitian ini dikelompokkan atas dua kelompok, yaitu siswa kelas $V_{A} S D N 2$ Maddukkelleng sebanyak 32 orang sebagai kelompok/kelas eksperimen $(X)$ dan siswa kelas $V_{B} S D N 5$
\end{abstract}


Maddukkelleng sebanyak 28 orang sebagai kelompok/kelas control (Y). Pengumpulan data dilakukan dengan cara memberi tes pada setiap kelompok. Data yang telah diperoleh dianalisis dengan menggunakan teknik statistik deskriptif dan teknik analisis eksperimen jenis uji $t$ desain ketiga. Hasil penelitian menunjukkan bahwa hasil perhitungan perbandingan koefisien nilai rata-rata kemampuan siswa menulis surat resmi antara kelas eksperimen $(X)$ dengan kelas kontrol $(Y)$ yang diperoleh sebesar 1,82 lebih besar dari t tabel pada taraf signifikan 95\% yaitu t.s. $0,95=1,70$, maka hipotesis alternatif $\left(H_{1}\right)$ diterima. Dengan demikian penggunaan media audiovisual efektif digunakan dalam meningkatkan kemampuan menulis surat resmi siswa SD Negeri Wilayah I Kecamatan Tempe Kabupaten Wajo. Berdasarkan hasil penelitian ini, penulis menyarankan agar dalam pembelajaran menulis surat resmi di Kelas V SD Negeri Wilayah I Kecamatan Tempe Kabupaten Wajo, sebaiknya menggunakan media audiovisual. Karena penggunaan media audiovisual mampu mengembangkan kreativitas dan imajinasi siswa, terutama dalam hal menemukan ide, mengembangkan dan menyusun tulisan yang lebih lebih lengkap, rapi, sistematis, utuh, dan padu. Hal ini dilakukan dengan tujuan agar siswa mampu meningkatkan kemampuan menulis surat resmi.

Kata kunci : audiovisual, menulis surat resmi

\section{PENDAHULUAN}

\section{A. Latar Belakang}

Keterampilan menulis merupakan salah satu keterampilan yang perlu dimiliki oleh siswa khususnya di SD yang dianggap sebagai langkah awal, karena sangat bermanfaat bagi pengembangan diri siswa. Keterampilan menulis merupakan bagian yang memerlukan keterampilan khusus yang sangat kompleks, mulai dari meneliti kata sampai pada penyusunan tulisan secara utuh. Selain itu, kemampuan yang perlu dimiliki seorang pelajar yaitu menguasai EYD, kata dan kalimat. Hal ini sejalan dengan yang dikemukakan oleh Morsey (Tarigan, 1992: 4) bahwa menulis dipergunakan oleh orang-orang terpelajar untuk mencatat/ merekam, meyakinkan, melaporkan/memberitahukan dan mempengaruhi.

Aspek membaca dan menyimak termasuk kegiatan reseptif yang menerima secara terbuka apa yang disampaikan kepada penulis atau pembaca, sedangkan keterampilan menulis dan membaca termasuk kegiatan produktif yang memproduksi tulisan dan wacana yang dapat dipahami atau dimengerti oleh orang lain.

Diantara dua pengklasifikasikan bahasa di atas, yang menjadi kajian penelitian ini adalah aspek produktif. Khususnya pada keterampilan menulis yaitu kemampuan menulis surat resmi siswa kelas V SD Negeri Wilayah I Kecamatan Tempe Kabupaten Wajo.

\section{LANDASAN TEORITIS}

\section{A. Pengertian Surat Resmi}

Dari uraian di atas menyebutkan tentang berbagai jenis surat yang salah satunya adalah surat resmi. Surat resmi adalah surat yang dibuat oleh suatu organisasi atau instansi, baik organisasi atau instansi swasta maupun pemerintah (Sumpriana, 1994: 11). Sementara menurut definisi yang lain, surat resmi adalah surat yang isinya menyangkut segi-segi 
kedinasan, baik yang dibuat instansi, organisasi, maupun perseorangan.

Dari berbagai pendapat para ahli tersebut, dapat disimpulkan bahwa surat resmi adalah surat yang berdasarkan segi kedinasan berupa organisasi atau instansi yang dibuat dengan memperhatikan kode etik surat itu sendiri.

\section{B. Jenis-Jenis Surat Resmi}

Menurut Sumpriana, (1994: 11), pada dasarnya surat resmi dapat dibagi tiga jenis, yaitu:

1. Surat Resmi Jabatan atau Dinas

Surat resmi jabatan atau dinas adalah surat-surat yang berisi masalahmasalah administrasi pemerintah yang dibuat atau dikeluarkan oleh instansi pemerintah. Surat jabatan sering juga disebut sebagai surat dinas pemerintah, yang meliputi:

a. Surat Tugas

Surat tugas adalah surat yang dikeluarkan oleh pihak atau instansi yang lebih tinggi, ditunjukkan kepada pihak bawahan agar bawahan tersebut melaksanakan suatu tugas atau pekerjaan tertentu.

b. Surat Perintah

Surat perintah adalah surat yang dikeluarkan oleh pihak yang lebih tinggi dan ditujukan kepada pihak yang lebih rendah (bawahan) agar bawahan tersebut berbuat atau tidak berbuat sesuatu sebagaimana diterangkan dalam surat tersebut.

c. Surat Instruksi

Surat instruksi adalah surat yang berisi perintah-perintah dengan petunjuk-petunjuk yang lengkap untuk dilaksanakan. d. Surat Keputusan

Surat keputusan adalah surat yang dikeluarkan oleh instansi yang diwakili oleh pimpinan yang tertinggi yang berisi pernyataan memutuskan sesuatu hal sehubungan dengan tertib organisasi yang bersangkutan.

e. Surat Rekomendasi

Surat rekomendasi adalah surat yang dibuat oleh seorang pimpinan, kepada atau pejabat tertentu, yang isinya menjelaskan atau menerangkan tentang keadaan pribadi seseorang.

f. Surat Referensi

Surat referensi adalah surat yang dibuat dan dikeluarkan apabila ada sebuah perusahaan yang memerlukan informasi tentang keadaan seseorang apakah dia alumni siswa suatu sekolah, bekas karyawan sebuah kantor, nasabah sebuah bank atau yang menjadi relasi sebuah perusahaan, karena perusahaan yang meminta keterangan tersebut ingin mengetahui tentang kepribadian yang bersangkutan.

g. Surat Perjalanan Dinas

Surat perjalanan dinas adalah surat perintah dan pimpinan kepada karyawan yang menjadi bawahannya untuk melaksanakan perjalanan dinas, kepada kantor cabang yang berada di tempat lain atau untuk menyelesaikan perintah kedinasan dengan kantor lain yang terkait yang berada di kota atau tempat lain.

2. Surat Resmi Organisasi/perhimpunan 
Surat resmi organisasi atau perhimpunan adalah surat-surat yang mencakup:

a. Surat pengantar adalah surat yang digunakan untuk mengantar sesuatu dengan maksud agar yang menerimanya mengetahui sesuatu yang diterimanya.

b. Surat pengumuman adalah surat yang berisi pemberitahuan tentang sesuatu hal perlu diketahui oleh seluruh anggota warga atau unit masyarakat atau pihak-pihak yang terkait dengan isi atau perihal yang tertera dalam surat tersebut.

c. Surat edaran adalah surat pemberitahuan secara tertulis yang ditujukan kepada banyak pihak.

d. Surat kuasa adalah surat yang dibuat untuk memberikan kekuasaan terhadap seseorang yang dapat dipercaya supaya bertindak mewakili orang yang memberi kuasa, karena orang yang memberi kuasa tidak dapat melaksanakannya sendiri.

e. Surat panggilan adalah surat-surat yang dikeluarkan oleh pihak yang satu ditujukan kepada pihak lainnya dengan maksud memanggilnya atau meminta datang untuk kepentingan tertentu baik pribadi maupun kedinasan pada hari, tanggal, tempat dan waktu yang telah ditentukan.

f. Surat peringatan adalah surat yang dibuat dan dikeluarkan oleh instansi, jawatan, atau perusahaan yang ditujukan kepada karyawannya atau relasinya yang melanggar ketentuan-ketentuan yang telah diterapkan.

3. Surat dagang Atau Niaga

Menurut Thomas (1995: 95) surat niaga yang sering dipakai adalah sebagai berikut:

a. Surat perkenalan adalah surat yang dibuat oleh penjual yang ditujukan kepada pembeli yang isinya memperkenalkan hasil produksi atau usaha dalam perniagaan disertai dengan keterangan-keterangan selengkapnya.

b. Surat permintaan daftar harga adalah surat yang dibuat dan dikirimkan oleh calon pembeli kepada penjual untuk meminta daftar harga atau katalogus dari barang-barang atau jasa-jasa tertentu yang dibutuhkannya.

c. Surat penawaran adalah surat yang dikirimkan kepada perusahaan atau konsumen guna memberikan tawaran tentang jual beli barang.

d. Surat pesanan atau dapat pula digolongkan sebagai jual beli.

e. Faktur dan rekening adalah surat tanda bukti bahwa barangbarang yang tercantum di dalamnya telah diperjualbelikan.

f. Surat pengantar barang. surat ini dapat menyertai daftar rincian surat jalan yang digunakan sebagai tanda terima penyerahan barang kepada penerima barang (pembeli atau pemesan)

g. Surat keluhan adalah surat yang dikirim instansi, perusahaan atau seseorang sebagai penghubung antara penjual barang dengan 
pembeli karena barang yang dibeli atau diterima oleh pembeli atau penerima tidak sesuai dengan kriteria yang diinginkannya.

h. Surat tuntutan penyelesaiannya adalah surat tuntutan ganti kerugian dari pihak pembeli kepada pihak penjual.

i. Surat gugat adalah surat yang lazim digunakan dalam upaya hukum yaitu untuk mengajukan perkara ke pengadilan guna proses dan diselesaikan dengan adil secara hukum.

j. Surat permohonan pembelian dan kredit adalah surat yang berisi permintaan pembelian dan melakukan pengkreditan barang.

k. Surat kredit adalah surat peringatan yang dikirim oleh kreditor atau penjual kepada debitur agar dia melunasi utangnya sesuai yang telah diperjualkan.

\section{Langkah-Langkah Surat Resmi}

Di bawah ini langkah-langkah penyusunan surat resmi yang dikemukakan oleh Thomas (1995: 15), yaitu:

1) Membuat perencanaan dan persiapan yang baik.

2) Menetapkan dan menguasai masalah yang akan diungkapkan.

3) Pokok masalah itu disusun lalu diuraikan secara sistematis, kronologis, runtut dan konsisten.

4) Menetapkan bahan dan data untuk menyusun surat.

5) Mengetahui siapa yang dituju.

6) Menyadari dan menentukan posisi penulis.
7) Menggunakan kelengkapan (fasilitas) yang memadai, penggunaan bentuk surat standar, jenis kertas yang dipakai HVS, warna putih bersih, ukuran kertas (folio, kwarto atau octavo), amplop surat dan cara melipat surat, pengetikan serta pengiriman (waktu yang tepat, jaminan keamanan isinya).

8) Meneliti kembali surat yang telah dikerjakan, apakah sudah benar dan layak dikirim atau belum.

\section{Bagian-bagian Surat Resmi}

Menurut Soedjito dan Solehan

(2004: 38), bagian-bagian surat resmi yang lengkap adalah sebagai berikut:

1) Kepala Surat

Kepala surat biasanya diketik sebelah kiri atas, boleh juga diketik disebelah kanan bawah.

2) Tanggal Surat

Tanggal surat biasanya diketik disebelah kiri atas (bentuk lurus penuh) dan kanan atas (lurus setengah lurus Indonesia). Boleh juga diketik sebelah kanan bawah.

3) Nomor Surat

Surat resmi selalu diberi nomor urut surat yang dikirimkan, kode, dan tahun. Nomor surat diketik segaris dengan tanggal, bulan, dan tahun (bentuk lurus, setengah lurus, dan Indonasi).

4) Lampiran

Melampirkan berarti menyertakan sesuatu dengan yang lain. Jika bersama surat yang dikirim itu disertakan dengan yang lain.

5) Hal atau Perihal 
Bagian ini menunjukkan isi atau inti surat secara singkat, dengan membaca hal atau perihal, secara cepat dapat diketahui masalah yang dituliskan dalam surat.

6) Alamat Surat

Ada dua macam alamat surat, yaitu alamat dalam (pada helai surat) dan alamat luar (pada amplop surat).

7) Salam Pembuka

Salam pembuka merupakan tanda hormat pengiriman surat sebelum dia berbicara secara tertulis. Dalam surat resmi yang biasa digunakan sebagai salam pembuka adalah Dengan hormat yang ditulis segaris lurus dengan baris-baris lainnya.

8) Isi Surat

Isi surat pada umumnya terdiri atas tiga bagian yaitu pembuka, isi yang sesungguhnya, dan penutup.

9) Salam Penutup

Salam penutup surat dinas atau formal pemerintahan menyebutkan nama jabatan (Rektor, Pembantu rektor I, Dekan dan sebagainya), tanda tangan, nama terang, dan NIP (Nomor Induk Pegawai).

10) Tembusan

Tembusan (c.c. $=$ carbon copy) dibuat jika isi surat yang dikirimkan kepada pihak yang sebenarnya dituju (asli) perlu diketahui olek pihak-pihak yang lain ada hubungannya surat tersebut. Dengan cara demikian yang dikirim surat mengerti siapa saja yang juga diberi tahu tentang isi surat itu.

\section{E. Bahasa Surat Resmi}

Menurut Soedjito dan Solehan (2004: 30). Bahasa resmi terbagi atas dua, yaitu:

1) Bahasa baku

Bahasa baku ialah bahasa yang mempunyai kaidah yang sudah dilazimkian.

2) Bahasa efektif

Bahasa efektif ialah bahasa yang secara tepat dapat mencapai sasarannya.

F. Pemanfaatan Media Audiovisual dalam Proses Belajar-Mengajar

Zulkarnain (1994:

menyebutkan implikasi media audiovisual diam dalam pembelajaran, yaitu:

1) Penggunaan audiovisual dapat merangsang siswa dan atau perhatian dari siswa.

2) Audiovisual yang dipilih dapat diadaptasikan secara tepat dan dapat membantu siswa memahami dan mengingat isi informasi bahan-bahan verbal yang menyertainya.

3) Audiovisual dengan garis-garis sederhana seringkali dapat lebih efektif digunakan sebagai penyampai informasi daripada dengan audiovisual bayangan, atau pun audiovisual yang sederhana. Audiovisual yang realis dan dilengkapi dengan informasi audiovisual yang terlalu banyak, ternyata kurang baik sebagai perangsang belajar dibandingkan audiovisual atau potret yang sederhana saja.

4) Warna pada audiovisual biasanya menimbulkan masalah. Sekalipun audiovisual berwama lebih dapat menarik perhatian mahasiswa daripada audiovisual yang hitam putih, namun 
tidak selamanya audiovisual merupakan pilihan terbaik untuk mengajar atau belajar. Suatu hasil penelitian menyarankan agar penggunaan warna haruslah menarik dan bukan sekadar memberikan warna saja, kecuali jika yang akan diajarkan itu memang menyangkut kondisi warna, maka audiovisual dengan warna yang memang lebih disukai.

5) Kalau bermaksud mengajarkan konsep soal gerak, sebuah gambar diam mungkin kurang efektif digunakan jika dibandingkan sepotong film bergerak yang menunjukkan gaya yang sama, Dalam hal ini, satu urutan gambar diam, seperti yang dibuat oleh kamera foto 35 $\mathrm{mm}$ dapat mengurangi informasi yang terlalu banyak ditampilkan oleh suatu film gerak.

6) Isyarat yang bersifat nonverbal atau simbol seperti tanda panah, atau pun tanda-tanda lainnya pada audiovisual dapat memperjelas atau mungkin pula mengubah pesan yang sebenarnya dimaksudkan untuk dikomunikasikan.

\section{G. Fungsi Media Audivisual sebagai Alat Peraga dalam Pembelajaran Menulis Surat Resmi}

Dalam suatu proses belajar mengajar, unsur media pembelajaran sangat penting. Pembelajaran tanpa menggunakan alat peraga dikenal juga sebagai bentuk pembelajaran tradisional dan yang paling umum digunakan adalah metode ceramah. Penggunaan metode ini dalam pembelajaran babasa Indonesia bersifat verbal karena dosen menyampaikan infoimasi hanya dalam bentuk lisan atau biasa disertai dengan penulisan di papan tulis (Hamalik, 1994: 35).

Levie dan Lentz (dalam Azhar, 2000: 16) mengemukakan bahwa ada empat fungsi media pembelajaran khususnya media visual, yaitu: 1) fungsi atensi, 2) fungsi afektif, 3) fungsi kognitif, dan 4) fungsi kompensatoris.

Fungsi atensi media visual yaitu menarik dan mengarahkan perhatian mahasiswa untuk berkonsentrasi kepada isi pelajaran yang beikaitan dengan makna visual yang ditampilkan atau menyertai teks materi pelajaran. Fungsi afeklif media visual dapat dilihat dari tingkat kenikmatan mahasiswa ketika belajar (membaca) teks yang bergerak (film). Fungsi kognitif media visual terlihat dari temuan-temuan pendidikan yang mengungkapkan bahwa lambang audiovisual memperlancar pencapaian tujuan untuk memahami dan mengingat informasi atau pesan yang terkandung dalam audiovisual. Fungsi kompensatoris media pembelajaran terlihat dari basil penelitian bahwa media visual yang memberikan konteks untuk memahami teks membantu mahasiswa yang lemah dalam membaca untuk mengorganisasikan informasi dalam teks dan mengingatnya kembali.

\section{METODE PENELITIAN}

\section{A. Jenis dan Lokasi Penelitian}

Penelitian ini merupakan penelitian kuantitatif karena menguji dua kelompok yaitu satu kelompok yang dikenai perlakuan dan satunya tidak dikenai perlakukan. Perlakuan yang dimaksud adalah penggunaan media audiovisual dalam pembelajaran menulis surat resmi 
pada siswa kelas V salah satu SD Negeri Wilayah I Kecamatan Tempe Kabupaten Wajo, yaitu siswa kelas $\mathrm{V}_{\mathrm{A}}$ SD Negeri 2 Maddukkelleng. Satu kelas lainnya tanpa perlakuan dalam pembelajaran menulis surat resmi, yaitu di kelas $\mathrm{V}_{\mathrm{B}}$ SD Negeri 5 Maddukkelleng yang juga termasuk dalam salah satu SD Negeri Wilayah I Kecamatan Tempe Kabupaten Wajo.

Lokasi penelitian ini adalah SD Negeri Wilayah I Kecamatan Tempe

\begin{tabular}{|lllll|}
\hline$R$ & $X$ & $O$ & 1 \\
\hline$R$ & -- & $O$ & 2 \\
\hline
\end{tabular}

Keterangan:

Keterangan :

$\mathrm{R}$ : Kelompok yang dipilih secara acak (kelas eksprimen dan kelas kontrol)

$\mathrm{X}$ : Perlakuan

_ : Tanpa perlakuan

O1 : Postes kelas eksprimen

O2 : Postes kelas kontrol

\section{Definisi Operasional Variabel}

Untuk memberikan gambaran operasional dari variabel-variabel yang diselidiki dalam penelitian ini, maka berikut dikemukakan definisi operasional untuk masing-masing variabel.

a. Surat resmi

Suatu sarana untuk menyampaikan pernyataan atau informasi secara tertulis dari yang satu ke pihak yang lain, baik atas nama sendiri, maupun atas nama jabatannya dalam sebuah organisasi, instansi ataupun perusahaan.

b. Media Audiovisual
Kabupaten Wajo yang dijadikan sampel penelitian, yaitu SD Negeri 2 Maddukkelleng dan SD Negeri 5 Maddukkelleng.

\section{B. Variabel dan Desain Penelitian}

Variabel dalam penelitian ini adalah penggunaan media audiovisual sebagai variabel bebas dan menulis surat resmi sebagai variabel terikat. Desain penelitian ini adalah posttest-Only Control Design, dapat dilihat pada gambar berikut ini.
Media audio berkaitan dengan pendengaran. Pesannya dituangkan dalam bentuk auditif. Media ini memiliki perangkat lunak (software) dan perangkat keras (hardware). Yang termasuk dalam alat peraga ini antara lain radio, alat perekam pita magnetik. Selanjutnya, visual yaitu berkaitan dengan penglihatan. Jadi, audiovisual yaitu media yang menyalurkan pesan kepada penerima melalui pemutaran film bergerak, seperti melalui CD, LCD, dan TV.

c. Pembelajaran Konvensional Yang dimaksud Pembelajaran konvensional adalah pembelajaran yang biasa diterapkan guru kelas $\mathrm{V}$ SD Negeri Wilayah I Kecamatan Tempe Kabupaten Wajo yaitu proses di mana guru menjelaskan, sementara siswa mencatat hal-hal yang dianggap penting, setiap 
selesai satu unit pelajaran diberi tes formatif untuk mengetahui tingkat pemahaman siswa terhadap materi yang beru diberikan.

\section{B. Populasi dan Sampel Penelitian}

1) Populasi penelitian
Populasi dalam penelitian ini adalah seluruh siswa kelas V SD Negeri Wilayah I Kecamatan Tempe Kabupaten Wajo pada tahun ajaran 2012/2013. Populasi tersebut meliputi 5 kelas, seperti yang tergambar dalam tabel berikut ini:

Tabel Populasi Penelitian

\begin{tabular}{|c|c|c|c|}
\hline Kelas & Pria & Wanita & Jumlah \\
\hline \multicolumn{4}{|c|}{ SD Negeri 2 Maddukelleng } \\
\hline $\mathbf{V}_{\mathbf{A}}$ & 15 & 17 & $\mathbf{3 2}$ \\
\hline $\mathbf{V}_{\mathbf{B}}$ & 15 & 14 & $\mathbf{2 9}$ \\
\hline $\mathbf{V}_{\mathbf{C}}$ & 16 & 15 & $\mathbf{3 1}$ \\
\hline \multicolumn{5}{|c|}{ SD Negeri 5 Maddukelleng } \\
\hline $\mathbf{V}_{\mathbf{A}}$ & 14 & 17 & $\mathbf{3 1}$ \\
\hline $\mathbf{V}_{\mathbf{B}}$ & 11 & 17 & $\mathbf{2 8}$ \\
\hline
\end{tabular}

(Sumber : Kesiswaan SD Negeri 2

Maddukelleng dan SD Negeri 5

Maddukelleng, 2012/2013)

Dari tabel di atas dapat diketahui bahwa jumlah populasi dalam penelitian ini sebanyak 151 siswa. Diasumsikan bahwa populasi dalam penelitian ini bersifat homogen karena penempatan siswa dalam suatu kelas tidak didasarkan pada tingkat prestasi belajar yang dicapai oleh siswa.

2) Sampel penelitian

Sampel dalam penelitian ini terdiri dari dua kelas yang dipilih sesuai dengan tujuan atau keinginan (sampling purposive). Satu kelas menjadi kelas eksperimen, yaitu kelas yang diajar dengan menggunakan media audiovisual, dan satu kelas menjadi kelas kontrol, yaitu kelas yang diajar dengan menggunakan pembelajaran konvensional. Kelas $\mathrm{V}_{\mathrm{A}}$ SD Negeri 2 Maddukkelleng dipilih sebagai kelas eksperimen, dan kelas $V_{B}$ SD Negeri 5 Maddukkelleng sebagai kelas kontrol. Seperti yang terdapat dalam tabel berikut ini: 
Tabel Sampel Penelitian

\begin{tabular}{|c|c|c|}
\hline & Kelas Sampel & $\begin{array}{c}\text { Jumlah } \\
\text { Siswa }\end{array}$ \\
\hline Kelas Eksperimen & $\mathrm{V}_{\mathrm{A}}$ SDN 2 Maddukkelleng & $\mathbf{3 2}$ \\
\hline Kelas Kontrol & $\mathrm{V}_{\mathrm{B}}$ SDN 5 Maddukkelleng & $\mathbf{2 8}$ \\
\hline
\end{tabular}

(Sumber : Kesiswaan SD Negeri 2

Maddukelleng dan SD Negeri 5

Maddukelleng, 2012/2013)

Jumlah sampel dalam penelitian sebanyak 60 siswa. Cara penarikan sampel dengan menggunakan teknik sampling purposive (Sugiyono, 2009):

\section{E. Teknik Pengumpulan Data}

Langkah-langkah pengumpulan data dalam penelitian ini adalah:

1. Peneliti melakukan observasi lapangan untuk mengetahui jumlah dan keadaan siswa.

2. Peneliti melakukan pembelajaran menulis dengan menguraikan konsep menulis dan surat resmi.

3. Peneliti memberikan perlakuan dengan implementasi media audiovisual dalam pembelajaran menulis surat resmi, sekaligus untuk mengukur perbedaan antara penggunaan media audiovisual dan tidak menggunakan media audiovisual dalam pembelajaran.

4. Memberikan skor hasil tes.

5. Pada akhirnya, peneliti melakukan kegiatan analisis data dengan menggunakan analisis deskriptif dan statistik inferensial.

\section{F. Teknik Analisis Data}

Dalam penelitian ini, data yang terkumpul dianalisis dengan menggunakan analisis deskriptif dan analisis eksperimen jenis uji $t$ desain ketiga. Hasil penelitian berupa bahan yang diperoleh dari sampel diolah dan dianalisis dengan menggunakan teknik statistik. Langkah-langkah dalam menganalisis data adalah sebagai berikut:

1) Membuat daftar skor mentah

2) Membuat distribusi frekuensi dari skor mentah

3) Untuk kepentingan standardisasi hasil pengukuran (skor) dilakukan transformasi dari skor mentah di dalam nilai berskala 1-10.

4) Menentukan frekuensi kuantitatif perolehan nilai. Sampel dikatakan tuntas, jika memperoleh nilai $70 \mathrm{ke}$ atas, dan dianggap tidak tuntas jika sampel memperoleh nilai di bawah 70.

5) Menentukan perbandingan hasil belajar kelas eksprimen dan kelas kontrol tentang kemampuan siswa menulis surat resmi dengan menggunakan media audiovisual, dengan menggunakan rumus uji $t$ desain.

6) Melakukan Uji Hipotesis

\section{HASIL PENELITIAN DAN PEMBAHASAN}

Penyajian hasil analisis data berikut bertujuan untuk mengetahui efektifitas penerapan media audiovisual 
dalam pembelajaran menulis surat resmi pada siswa kelas V SD Negeri Wilayah I Kecamatan Tempe Kabupaten Wajo dan untuk mengungkapkan keefektifan penerapan penggunaan media audiovisual dalam pembelajaran menulis surat resmi pada siswa kelas V SD Negeri Wilayah I Kecamatan Tempe Kabupaten Wajo.
A. Analisis Data kemampuan Siswa Menulis Surat Resmi Menggunakan Media Audiovisual pada Kelas Eksperimen (X)

1. Pretes

Jumlah Nilai Hasil (Pre-test) Kemampuan

Siswa Menulis Surat Resmi Kelas

Eksperimen $\left(\sum X\right)$ secara Keseluruhan

\begin{tabular}{|c|c|c|c|}
\hline No. & Nilai (X) & Frekuensi (N) & Jumlah Nilai $\sum \boldsymbol{X}$ \\
\hline 1. & 6 & 10 & 60 \\
\hline 2. & 5 & 9 & 45 \\
\hline 3. & 4 & 10 & 40 \\
\hline 4. & 3 & 3 & 9 \\
\hline \multicolumn{3}{|c|}{ Jumlah } & $\mathbf{3 2}$ \\
\hline
\end{tabular}

Dari tabel 4.4 diketahui bahwa nilai siswa sampel $(\mathrm{N})$ atau $\left(\sum X / \mathrm{N}=154 / 32\right.$ $=4,81$ ).

2. Postes

rata-rata hasil (pre-test) kemampuan siswa menulis surat resmi kelas eksperimen adalah 4,81 yang diperoleh dari hasil bagi jumlah seluruh nilai kemampuan menulis surat resmi siswa $\left(\sum X\right)$ dengan jumlah

Jumlah Nilai Hasil (Post-test) Kemampuan

Siswa Menulis Surat Resmi Kelas

Eksperimen $\left(\sum X\right)$ secara Keseluruhan

\begin{tabular}{|c|c|c|c|}
\hline No. & Nilai (X) & Frekuensi (N) & Jumlah Nilai $\sum \boldsymbol{X}$ \\
\hline 1. & 10 & 5 & 50 \\
\hline 2. & 9 & 9 & 81 \\
\hline 3. & 8 & 5 & 40 \\
\hline 4. & 7 & 10 & 70 \\
\hline 5. & 6 & 2 & 12 \\
\hline 6. & 5 & 1 & 5 \\
\hline & Jumlah & $\mathbf{3 2}$ & $\mathbf{2 5 8}$ \\
\hline & Rata-rata & $\mathbf{8 , 0 6}$ \\
\hline
\end{tabular}

Dari tabel 4.7 diketahui bahwa nilai rata-rata hasil (post-test) kemampuan siswa menulis surat resmi kelas eksperimen adalah 8,06 yang diperoleh dari hasil bagi jumlah seluruh nilai kemampuan menulis surat resmi siswa ( $\sum X$ ) dengan jumlah siswa sampel $(\mathrm{N})$ atau $\left(\sum X / \mathrm{N}=\right.$ $258 / 32=8,06)$. 
Klasifikasi Kelulusan Siswa Kelas Eksperimen (X)

\begin{tabular}{|c|c|c|c|}
\hline No. & Nilai & Frekuensi & $\begin{array}{c}\text { Presentase } \\
\text { (\%) }\end{array}$ \\
\hline 1. & Nilai 70 ke atas... & 29 & 90,62 \\
\hline 2. & Nilai di bawah $70 \ldots$ & 3 & 9,38 \\
\hline \multicolumn{2}{|c|}{ Jumlah } & $\mathbf{3 2}$ & $\mathbf{1 0 0 \%}$ \\
\hline
\end{tabular}

Dalam tabel dapat diketahui bahwa sampel yang memperoleh nilai 70 ke atas, sebanyak 29 orang, sedangkan sampel yang memperoleh nilai di bawah 70 sebanyak 3 orang. Dengan demikian, sampel yang mencapai ketuntasan belajar pada kompetensi dasar menulis surat resmi hasil dari post-test di kelas eksperimen sebanyak 29 orang $(90,62 \%)$, sedangkan sampel yang dinyatakan tidak mencapai ketuntasan ada 3 orang $(9,38 \%)$.

\section{B. Analisis Data kemampuan Siswa Menulis Surat Resmi Menggunakan Media audiovisual pada Kelas Kontrol (Y)}

1. Pretes

Jumlah Nilai Hasil (Pre-test) Kemampuan Siswa Menulis Surat Resmi Kelas Kontrol $\left(\sum Y\right)$ secara Keseluruhan

\begin{tabular}{|c|c|c|c|}
\hline No. & Nilai (X) & Frekuensi (N) & Jumlah Nilai $\sum \boldsymbol{Y}$ \\
\hline 1. & 7 & 1 & 7 \\
\hline 2. & 6 & 9 & 54 \\
\hline 3. & 5 & 12 & 60 \\
\hline 4. & 4 & 6 & 24 \\
\hline \multicolumn{2}{r|}{ Jumlah } & $\mathbf{2 8}$ & $\mathbf{1 4 5}$ \\
\hline & Rata-rata & $\mathbf{5 , 1 8}$ \\
\hline
\end{tabular}

Dari tabel 4.12. diketahui bahwa nilai rata-rata hasil (pre-test) kemampuan siswa menulis surat resmi kelas kontrol adalah 5,18 yang diperoleh dari hasil bagi jumlah seluruh nilai kemampuan menulis surat resmi siswa ( $\sum Y$ ) dengan jumlah siswa sampel $(\mathrm{N})$ atau $\left(\sum Y / \mathrm{N}=145 / 28\right.$ $=5,18)$.

2. Postes

Jumlah Nilai Hasil (Post-test) Kemampuan Siswa Menulis Surat Resmi Kelas Kontrol

$\left(\sum Y\right)$ secara Keseluruhan 


\begin{tabular}{|c|c|c|c|}
\hline No. & Nilai (X) & Frekuensi (N) & Jumlah Nilai $\sum \boldsymbol{Y}$ \\
\hline 1. & 6 & 8 & 48 \\
\hline 2. & 5 & 10 & 50 \\
\hline 3. & 4 & 6 & 24 \\
\hline 4. & 3 & 4 & 12 \\
\hline \multicolumn{2}{|c|}{ Jumlah } & $\mathbf{2 8}$ & $\mathbf{1 3 4}$ \\
\hline & Rata-rata & $\mathbf{4 , 7 9}$ \\
\hline
\end{tabular}

Dari tabel 4.15. diketahui bahwa nilai rata-rata hasil (post-test) kemampuan siswa menulis surat resmi kelas kontrol adalah 4,79 yang diperoleh dari hasil bagi jumlah seluruh nilai kemampuan menulis surat resmi siswa ( $\sum Y$ ) dengan jumlah siswa sampel $(\mathrm{N})$ atau $\left(\sum Y / \mathrm{N}=\right.$ $134 / 28=4,79$ ).

\section{Pembahansan}

Penelitian ini merupakan penelitian eksperimen yang melibatkan dua kelompok, yaitu kelompok/kelas eksperimen (kelompok/kelas yang menggunakan media audiovisual dalam pembelajaran menulis surat resmi) dan kelompok/kelas kontrol (kelompok/kelas yang tidak menggunakan media audiovisual pembelajaran menulis surat resmi).

Kemampuan siswa di kelas kontrol dalam menulis surat resmi tidak menunjukkan hasil yang maksimal, ini disebabkan karena tidak adanya penggunaan teknik/metode pembelajaran yang dapat menarik perhatian siswa, dalam hal ini proses pembelajaran dilakukan seperti halnya proses pembelajaran biasa (metode konvensional).

\section{Zulkarnain (1994: 23-24)}

menyebutkan implikasi media audiovisual diam dalam pembelajaran, yaitu: Penggunaan audiovisual dapat merangsang siswa atau perhatian siswa. Audiovisual yang dipilih dapat diadaptasikan secara tepat dan dapat membantu siswa memahami dan mengingat isi informasi bahan-bahan verbal yang menyertainya. Sejalan dengan pendapat tersebut, maka dalam penelitian ini Media audiovisual dapat membantu siswa lebih kreatif dalam menulis surat resmi karena siswa dihadapkan langsung dengan media audiovisual untuk pengamatan secara langsung sehingga anak bisa cepat mencari ide atau gagasan untuk melahirkan sebuah kreativitas dalam menulis surat resmi.Metode the real things media dapat membantu siswa lebih kreatif dalam menulis karangan deskripsi karena siswa dihadapkan langsung dengan benda-benda nyata yang ada di lapangan atau dengan membawa narasumber atau benda-benda ke dalam sekolah untuk pengamatan secara langsung sehingga anak bisa cepat mencari ide atau gagasan untuk melahirkan sebuah kreativitas dalam menulis karangan deskripsi.

\section{KESIMPULAN}

\section{A. Kesimpulan}

Nilai rata-rata hasil pre-test kemampuan siswa menulis surat resmi yang tidak diberikan tindakan/treatment 
menggunakan media audiovisual (kelas kontrol) adalah 5,18. Pembelajaran siswa menulis surat resmi dengan menggunakan media audiovisual menunjukkan keaktifan siswa dalam mengikuti pembelajaran. Siswa mengikuti pembelajaran dengan baik. Nilai rata-rata hasil pre-test kemampuan siswa menulis surat resmi sebelum diberikan tindakan/treatment menggunakan media audiovisual adalah 4,81 .

Nilai rata-rata hasil post-test kemampuan siswa menulis surat resmi yang diberikan tindakan/treatment menggunakan media audiovisual (kelas eksperimen) adalah 8,06 , sedangkan nilai rata-rata hasil post-test kemampuan siswa menulis surat resmi yang tidak diberikan tindakan/treatment menggunakan media audiovisual (kelas kontrol) adalah 4,79. Hasil ini menunjukkan bahwa hasil kemampuan siswa menulis surat resmi yang diberikan tindakan/treatment menggunakan media audiovisual (kelas eksperimen) lebih tinggi sekitar 3,27 poin daripada siswa yang tidak diberi treatment/tindakan (kelas kontrol). Dengan demikian, maka penggunaan media audiovisual efektif digunakan dalam pembelajaran menulis surat resmi siswa SD Negeri Wilayah I Kecamatan Tempe Kabupaten Wajo.

\section{B. Saran}

Berdasarkan hasil penelitian ini penulis menyarankan agar dalam pembelajaran menulis, khususnya menulis surat resmi di SD Negeri Wilayah I Kecamatan Tempe Kabupaten Wajo, sebaiknya menggunakan media audiovisual. Karena media audiovisual mampu mengembangkan kreativitas dan imajinasi siswa, terutama dalam menemukan ide, mengembangkan dan menyusun tulisan yaitu surat resmi yang lebih lengkap, rapi, sistematis, utuh, dan padu. Hal ini dilakukan dengan tujuan agar siswa mampu meningkatkan kemampuan menulis surat resmi.

\section{DAFTAR PUSTAKA}

Ahmadi, Nursin. 1990. Dasar-Dasar Komposisi Bahasa Indonesia. Malang: Penerbit YE.

Alwi, H., dkk. 2003. Kamus Besar Bahasa Indonesia. Edisi Ketiga. Jakarta: Balai

Pustaka.

Ambo Enre, Fachruddin, dkk. 1995. Pembinaan Kemampuan Menulis Bahasa Indonesia. Jakarta: Erlangga.

Arifin E. Zaenal. 1993. Seribu Satu Kesalahan Berbahasa. Jakarta: Pressindo.

Arikunto, S. 1998. Prosedur Penelitian: Suatu Pendekatan Praktis. Jakarta: Rineka Cipta.

Fatmawati. 2004. ''Kemampuan Menulis Surat Pribadi Bahasa Bugis Kelas VIII SMP Cangking Kabupaten Bulukumba". Skripsi. (tidak diterbitkan). Makassar: Universitas Muhammadiyah Makassar. 
Hartati. 2006. Analisis Penggunaan Ejaan Bahasa Indinesia yang Disempurnakan dalam Surat Menyurat di Kantor Kecamatan Lalabata Kabupaten Soppeng. Skripsi. (tidak diterbitkan). Makassar: FBS Universitas Negari Makassar.

Munirah. 2005. Dasar Keterampilan Menulis. Diktat. Makassar: FKIP Unismuh.

Nurgiantoro. B. 1995. Penelitian Pengajaran Bahasa dan Sastra. Jogjakarta: BPFE.

Poerwadarminta. W. J. S. 1983. $A$ B $C$ Karang Mengarang. Jogjakarta: U. P. Indonesia.

Poerwadarminta. W. J. S. 2006. Kamus Umum Bahasa Indonesia. Edisi Ketiga. Jakarta: Balai Pustaka.

Ramlan. M. 1981. Sintaksis. Yogyakarta: U P. Karyono.

Sasongko. 2004. Pengembangan Perangkat Pembelajaran Matematika. http://Setyono.blospot.com/2008/ 07/tipe-tipe pengembangan perangkat pembelajaran. Diakses 8 Februari 2013.

Soedjito. 2010. Terampil Menulis Surat Resmi Bahasa Indonesia. Edisi Pertama. Jakarta: Prestasi Pustakaraya.
Soedjito dan Solehan. T. W. 2004. Surat Menyurat Resmi Bahasa Indonesia. Bandung: aremaja Rosdakarya.

Suhendar dan Supinah. 1992. MKDU Bahasa Indonesia. Bandung: Penerbit Pionir Jaya. 